\title{
Effect of addition of FSH, LH and proteasome inhibitor MG132 to in vitro maturation medium on the developmental competence of yak (Bos grunniens) oocytes
}

Xiao Xiao ${ }^{1}$, Xiang-Dong Zi $i^{*}$, Hui-Ran Niu', Xian-Rong Xiong ${ }^{1}$, Jin-Cheng Zhong ${ }^{2}$, Jian Li², Li Wang ${ }^{1}$ and Yong Wang ${ }^{2}$

\begin{abstract}
Background: The competence for embryonic development after IVF is low in the yak, therefore, we investigated the effects of supplementation of FSH, LH and the proteasome inhibitor MG132 in IVM media on yak oocyte competence for development after IVF.

Methods: In Experiment 1, yak cumulus-oocyte complexes (COCs) were in vitro matured (IVM) in TCM-199 with $20 \%$ fetal calf serum (FCS), $1 \mathrm{microg} / \mathrm{mL}$ estradiol-17beta, and different combinations of $\mathrm{LH}$ (50 or $100 \mathrm{IU} / \mathrm{mL}$ ) and $\mathrm{FSH}(0,1,5,10 \mathrm{microg} / \mathrm{mL})$ at 38.6 degrees $\mathrm{C}_{1} 5 \% \mathrm{CO}_{2}$ in air for $24 \mathrm{~h}$. Matured oocytes were exposed to frozen-thawed, heparin-capacitated yak sperm. Presumptive zygotes were cultured in SOF medium containing $6 \mathrm{mg} / \mathrm{ml} \mathrm{BSA}, 0.5 \mathrm{mg} / \mathrm{mL}$ myoinositol, 3\% ( $\mathrm{v} / \mathrm{v}$ ) essential amino acids, 1\% nonessential amino acids and $100 \mathrm{\mu g} / \mathrm{mL}$ L-glutamine (48 h, 38.5 degrees $\mathrm{C}, 5 \% \mathrm{CO}_{2}, 5 \% \mathrm{O}_{2}$, and $90 \% \mathrm{~N}_{2}$ ). In Experiment 2, cumulus cells were collected at the end of IVM to determine FSHR and LHR mRNA expression by real-time PCR. In Experiment 3 and 4, COCs were cultured in the presence or absence of the proteasomal inhibitor MG132 from either 0-6 h or 18-24 h after initiation of maturation.

Results: The optimum concentration of FSH and LH in IVM media was 5 microg/mL FSH and $50 \mathrm{IU} / \mathrm{mL}$ LH which resulted in the greatest cleavage (79.1\%) and blastocyst rates (16.1\%). Both FSHR and LHR mRNA were detected in yak cumulus cells after IVM. Treatment with MG132 early in maturation reduced $(P<0.05)$ cleavage and blastocyst rates. Conversely, treatment with MG132 late in maturation improved $(P<0.05)$ blastocyst rate. Optimal results with MG132 were achieved at a concentration of 10 microM.
\end{abstract}

Conclusions: An optimum concentration of FSH and LH in IVM medium, and treatment with MG132 late in maturation can improve yak oocytes competence for development after IVF.

Keywords: IVF, Yak, FSH, MG132, Early development

\footnotetext{
* Correspondence: zixd2000@yahoo.com

${ }^{1}$ College of Life Science and Technology, Southwest University for

Nationalities, Chengdu 610041, People's Republic of China

Full list of author information is available at the end of the article
} 


\section{Background}

In most mammals, throughout follicular development, the oocytes undergo a series of profound changes involving both nuclear and cytoplasmic maturation induced by the pre-ovulatory surge of gonadotropins during this period [1]. These changes are essential for the formation of oocytes having the capacity for fertilization and embryonic development. Therefore, in vitro culture systems of most species often occur in in vitro maturation (IVM) media supplemented with gonadotrophins such as FSH and LH to induce cumulus cell expansion, nuclear maturation, cytoplasmic maturation, and to improve embryonic development in mice [2,3], pig [4], cow [5], equine [6] and domestic dog [7]. For gonadotrophins to act in vitro, FSH and LH receptor (FSHR and LHR) proteins and mRNA must be expressed by the cumulus cell [8]. The proteasome, a multisubunit proteolytic complex involved in degradation of ubiquitinated proteins, plays a crucial role in assuring completion of meiosis and early in maturation of oocyte, however, late in the process of oocyte maturation, the proteasome may contribute to a reduction in the functional properties of the oocyte. Treatment with the proteasome inhibitor MG132 reduced the effect of in vitro aging on oocyte competence in the mouse [9]. Furthermore, treatment of oocytes with MG132 late in maturation increased abundance of specific transcripts and improved developmental competence of parthenogenetically-activated oocytes in the pig [10] and in vitro matured oocytes in cattle [11].

The yak (Bos grunniens) is the principal meat and dairy animal in Qinghai-Tibet plateau, because few other animals survive in these areas [12]. In vitro production (IVP) of embryos is a well-established embryonic biotechnology with a variety of application in basic and applied sciences. IVP has been made great progress in cattle which is becoming one of the most exciting and progressive procedures available for today's producers but the efficiency of yak IVP is still low, i.e. less than $10 \%$ of cleaved embryos (i.e., that were $\geq 2$ cells) becoming blastocysts $[13,14]$. Therefore, this study was performed to investigate the effect of FSH, LH and MG132 during oocytes maturation on competence for development after fertilization in the yak.

\section{Methods \\ Materials}

Dulbecco's phosphate-buffered saline (DPBS) was purchased from Hyclone Laboratories Inc. (Logan, UT), FSH from Bioniche Inc. (Belleville, Ontario, Canada) and fetal calf serum (FCS) from Gibco (Grand Island, NY). All other chemicals and reagents were cell-culture tested and were obtained from Sigma-Aldrich (St. Louis, MO). Synthetic oviductal fluid (SOF) medium was prepared according to the formula of Tervit et al. [15] minus glucose. All media were filtered through $0.2 \mu \mathrm{m}$ Millipore filter (Carrigtwohill, Co. Cork, Ireland) and placed in an incubator (Forma Serial II, USA) to equilibrate for four to six hours in an atmosphere of $5 \% \mathrm{CO}_{2}$ in air.

\section{Oocyte collection and in vitro maturation (IVM)}

Collection and IVM of yak oocytes were performed in accordance with the method of $\mathrm{Zi}$ et al. [13,16]. Briefly, ovaries were collected from yaks at local abattoir from October to December, and transported to the laboratory in DPBS maintained at $29-33^{\circ} \mathrm{C}$. Cumulus-oocyte complexes (COCs) were aspirated from follicles $(2-8 \mathrm{~mm}$ diameter) using a hand-held $10-\mathrm{ml}$ syringe connected to an 18 ga needle. COCs were collected in DPBS supplemented with $6 \mathrm{mg} / \mathrm{ml}$ BSA under a low-power $(20 \times)$ stereomicroscope. Unselected COCs were rinsed three times in DPBS containing 5\% (v/v) FCS and twice in TCM 199 supplemented with $20 \%$ (v/v) FCS, $1 \mu \mathrm{g} / \mathrm{ml}$ estradiol$17 \beta, 100 \mathrm{U} / \mathrm{ml}$ penicillin and $100 \mu \mathrm{g} / \mathrm{ml}$ streptomycin, different concentrations of FSH and $\mathrm{LH}$ according to the experimental design (IVM medium). Only COCs having one or more layers of cumulus cells and evenly granulated ooplasm were selected. Up to 30 COCs were placed in each culture well (Nunc Inc., Naperville IL, USA) containing $600 \mu \mathrm{l}$ of maturation medium covered with $300 \mu \mathrm{l}$ mineral oil. COCs were allowed to mature for approximately $24 \mathrm{~h}$ at $38.6^{\circ} \mathrm{C}$ in an atmosphere of $5 \% \mathrm{CO}_{2}$ in humidified air.

\section{Sperm preparation, in vitro fertilization, and embryo culture}

Sperm preparation and IVF were conducted according to previously described procedures $[13,16]$ with some modifications. Frozen semen was thawed and washed by centrifugation through a Percoll gradient $(30 \% / 45 \%)$ containing Hepes-buffered SOF medium supplemented with $5 \mathrm{mg} / \mathrm{ml}$ BSA, $50 \mu \mathrm{g} / \mathrm{ml}$ caffeine, $30 \mu \mathrm{g} / \mathrm{ml}$ glutathione and $20 \mu \mathrm{g} /$ $\mathrm{ml}$ heparin (sperm medium) and centrifuged at $500 \times \mathrm{g}$ for $10 \mathrm{~min}$ to separate motile sperm. After centrifugation, $120 \mu \mathrm{l}$ of the concentrated sperm fraction was removed and placed into $200 \mu \mathrm{l}$ of sperm medium and incubated at $38.6^{\circ} \mathrm{C}$ for $15 \mathrm{~min}$.

After oocyte maturation, excess cummulus cells were removed by gently swirling the COCs in a $36 \mathrm{~mm}$ Petri dish containing SOF with $6 \mathrm{mg} / \mathrm{ml}$ BSA (IVF medium). The COCs were further washed twice in IVF medium before being transferred into four-well plates (up to 30 per well) containing $500 \mu \mathrm{l}$ IVF medium covered with $300 \mu \mathrm{l}$ mineral oil per well. Each well received $50 \mu \mathrm{l}$ of the sperm suspension (for a final concentration of $1 \times 10^{6}$ motile sperm $/ \mathrm{ml}$ ). Oocytes and sperm were allowed to coincubate for $24-26 \mathrm{~h}$ at $38.6^{\circ} \mathrm{C}$ in an atmosphere of $5 \% \mathrm{CO}_{2}$ in humidified air. Remnant cumulus cells were removed from the putative zygotes by gentle pipetting after approximately 
$26 \mathrm{~h}$ of coincubation. The putative zygotes were then washed three times in SOF medium. Groups of $25 \mathrm{em}-$ bryos were cultured in $600 \mu \mathrm{l}$ of SOF medium supplemented with $6 \mathrm{mg} / \mathrm{ml} \mathrm{BSA}, 0.5 \mathrm{mg} / \mathrm{ml}$ myoinositol, $3 \%$ $(\mathrm{v} / \mathrm{v})$ essential amino acids, $1 \%(\mathrm{v} / \mathrm{v})$ nonessential amino acids, $100 \mathrm{U} / \mathrm{ml}$ penicillin, $100 \mu \mathrm{g} / \mathrm{ml}$ streptomycin and $100 \mu \mathrm{g} / \mathrm{ml} \mathrm{L}$-glutamine (culture medium) under $300 \mu \mathrm{l}$ mineral oil, cultured in a humidified atmosphere of $5 \%$ $\mathrm{CO}_{2}, 5 \% \mathrm{O}_{2}$, and $90 \% \mathrm{~N}_{2}$ at $38.5^{\circ} \mathrm{C}$. The number of $\mathrm{zy}-$ gotes that cleaved was recorded $48 \mathrm{~h}$ post insemination (hpi). The culture medium was changed at $96 \mathrm{hpi}$ and blastocyst development was determined on Days 7 to 9 post insemination (Day $0=$ insemination). This experiment was replicated three to five times for each group.

\section{Expression of $F S H R$ and $L H R$ in cumulus cells after in vitro maturation}

GAPDH gene was chosen as reference gene for normalizing expression levels of target genes. Primers specific for target goat genes were designed with Beacon Designer 7.0 software (Premier Biosoft International, Palo Alto, CA USA) according to manufacturers guidelines (FSHR: 5'-T TCAATGGGACAACGCTGATTTC-3'/5'-T GTGGCAAT TAGCGTCTGAATG GA-3'; LHR: 5'-AGTGACACCAA GATAGCCAAGC-3/5-GGTAGAACAGGACCAGGAGG AT-3'; GAPDH: 5'-AGTTCCACGGCACAGTCAAG-3'/ 5'-ACTCAGCACCAGCATCACC- 3'). Total RNA of cumulus cells after in vitro maturation (different concentrations of FSH and LH in IVM medium) was extracted, and reverse transcribed as described previously [17]. Real-time PCR was performed using on an iCycler iQ5 Real-time Detection System (Bio-Rad, CA, USA) with the SsoFast ${ }^{\text {Ts }}$ EvaGreen Supermix (Bio-Rad, CA, USA) in a volume of $10 \mu \mathrm{l}$. The cycle parameters were $3 \mathrm{~min}$ at $95^{\circ} \mathrm{C}$, followed by 45 cycles of denaturation at $95^{\circ} \mathrm{C}$ for $10 \mathrm{~s}$ and annealing at $60.7^{\circ} \mathrm{C}(F S H R), 58.9^{\circ} \mathrm{C}(L H R)$ or $57.7^{\circ} \mathrm{C}(G A P D H)$ for $10 \mathrm{~s}$, and finally, melt curve analysis. The real-time PCR amplification efficiency $(E)$ of each primer pair and mean $\mathrm{Ct}$ (threshold cycles) values were calculated and used for determination of target gene RNA transcript levels [18], which includes a correction for differences in $E$ between the target and housekeeping gene. Results were expressed, however, as relative expression ratios $(R E)$ rather than as fold changes from a calibrator sample. The formula, therefore, was as $R E=(1+E \text { ref })^{C t}$ ref $/(1+E \text { target })^{C t}$ target. Each sample was tested in triplicate, and each experiment was replicated four times with cumulus cells from 30-50 COCs for each replicate.

\section{Experimental design}

Experiment 1 was conducted to investigate the optimal concentration of FSH and LH in IVM medium to improve yak oocyte competence for development after fertilization. COCs were matured in IVM medium that was supplemented with different combinations of $\mathrm{LH}$ (50 or $100 \mathrm{IU} / \mathrm{ml})$ and FSH $(0,1,5,10 \mu \mathrm{g} / \mathrm{ml})$.

Experiment 2 was conducted to investigate the effect of addition of FSH and LH in IVM media on FSHR and LHR mRNA expression in cumulus cells after $24 \mathrm{~h}$ IVM. COCs were matured in IVM medium that was supplemented with different combinations of LH $(0,50$ or $100 \mathrm{IU} / \mathrm{ml})$ and FSH $(0,1,5,10 \mu \mathrm{g} / \mathrm{ml})$. Cumulus cells were collected at the end of IVM for each combination to determine FSHR and LHR mRNA expression.

Experiment 3 was conducted to investigate the concen tration-dependent effects of MG132 added at the end of oocyte maturation on embryonic development. The MG132 was dissolved in dimethyl sulfoxide (DMSO) and was added to maturation drops so that the final concentration of DMSO was not greater than $0.5 \%(\mathrm{v} /$ v). The control oocytes were cultured with medium supplemented with a similar amount of DMSO during IVM as for oocytes treated with MG132. COCs were matured in IVM medium (containing $5 \mu \mathrm{g} / \mathrm{ml} \mathrm{FSH}$ and $50 \mathrm{IU} / \mathrm{ml}$ $\mathrm{LH})$ that was supplemented with $0,10,20$ or $30 \mu \mathrm{M}$ MG132 from $18 \mathrm{~h}$ to $24 \mathrm{~h}$ after initiation of maturation. Treatment was achieved by washing COCs after $18 \mathrm{~h}$ of maturation and placing them in fresh medium containing MG132.

Experiment 4 was conducted to determine whether timing of MG132 treatment altered effects of the inhibitor on embryonic development. COCs were untreated or treated with $10 \mu \mathrm{M}$ MG132 at two times [0-6 h of maturation (during the initiation of maturation) or 18-24 h of maturation (at the end of maturation)] using a $2 \times 2$ factorial arrangement of treatments. The COCs were placed in appropriate treatments at $0 \mathrm{~h}$ (MG132), washed at $6 \mathrm{~h}$, placed in fresh IVM medium (containing $5 \mu \mathrm{g} / \mathrm{ml} \mathrm{FSH}$ and $50 \mathrm{IU} / \mathrm{ml} \mathrm{LH}$ ) without MG132, washed at $18 \mathrm{~h}$ of maturation, and placed in fresh medium with appropriate treatment. Thus, some cultures received MG132 at 0-6 $\mathrm{h}$ and $18-24 \mathrm{~h}$, some received MG132 from 0-6 h only, some received MG132 from 18-24 h only, and some did not receive MG132 treatment during in vitro maturation.

\section{Statistics}

Data were analyzed statistically as follows. For each replicate, percentage of oocytes that cleaved and percentage of cleaved embryos that became blastocysts were calculated for all oocytes or embryos within the same treatment. Thus, the group of oocytes treated alike within each replicate was the experimental unit. Statistical analyses were performed using the Statistical Analysis System (version 9.2, SAS Institute Inc., Cary, NC, USA). Data were analyzed using the General Linear Models procedure. Percentage data were arcsine- transformed prior to analysis to maintain homogeneity of variance. 
Table 1 Effects of FSH and LH concentration in IVM medium on yak embryonic development

\begin{tabular}{ccccc}
\hline $\begin{array}{c}\mathbf{L H} \\
(\mathbf{I U} / \mathbf{m L})\end{array}$ & $\begin{array}{c}\mathbf{F S H} \\
(\boldsymbol{\mu} \mathbf{g} / \mathbf{m L})\end{array}$ & $\begin{array}{c}\text { No. of } \\
\text { oocytes }\end{array}$ & Cleavage rate (\%) & $\begin{array}{c}\text { Blastocyst } \\
\text { rate (\%) }\end{array}$ \\
\hline 50 & 0 & 233 & $50.6 \pm 2.2^{\mathrm{a}}$ & $10.3 \pm 1.8^{\mathrm{a}}$ \\
& 1 & 171 & $73.1 \pm 2.9^{\mathrm{b}}$ & $11.9 \pm 1.3^{\mathrm{a}}$ \\
& 5 & 173 & $79.1 \pm 2.0^{\mathrm{b}}$ & $16.1 \pm 2.9^{\mathrm{b}}$ \\
& 10 & 265 & $65.6 \pm 2.5^{\mathrm{c}}$ & $12.7 \pm 2.8^{\mathrm{a}}$ \\
100 & 0 & 194 & $47.3 \pm 2.5^{\mathrm{a}}$ & $9.6 \pm 1.1^{\mathrm{a}}$ \\
& 1 & 181 & $58.9 \pm 2.3^{\mathrm{a}}$ & $12.3 \pm 1.3^{\mathrm{a}}$ \\
& 5 & 190 & $67.5 \pm 1.8^{\mathrm{c}}$ & $14.5 \pm 2.6^{\mathrm{a}}, \mathrm{b}$ \\
& 10 & 254 & $64.2 \pm 2.7^{\mathrm{c}}$ & $13.4 \pm 1.8^{\mathrm{a}}$ \\
\hline
\end{tabular}

Three to five replicates were performed. The blastocyst rate was calculated as the percentage of the number of cleaved embryos. Values with different letters within the same columns differ $(P<0.05)$
Results are expressed as least-squares means \pm standard error (SE) of the untransformed data.

\section{Results}

The optimal concentration of FSH and LH in IVM medium (Experiment 1)

Effects of FSH and LH concentration in IVM medium on subsequent embryonic development of the yak were shown in Table 1. The optimal concentration of FSH and $\mathrm{LH}$ in IVM medium was $5 \mu \mathrm{g} / \mathrm{ml} \mathrm{FSH}$ and $50 \mathrm{IU} / \mathrm{ml} \mathrm{LH}$, i.e. both the cleavage rate and the blastocyst rate were the highest at this condition. There was a tendency for high $\mathrm{LH}$ concentration $(100 \mathrm{IU} / \mathrm{ml})$ in IVM medium to decrease the subsequent cleavage rate.

Effect of addition of FSH and LH in IVM media on FSHR and LHR mRNA expression in cumulus cells (Experiment 2)

FSHR and LHR mRNA expressions of cumulus cells in media supplemented with different concentrations of FSH and LH were shown in Figure 1. Both FSHR and LHR
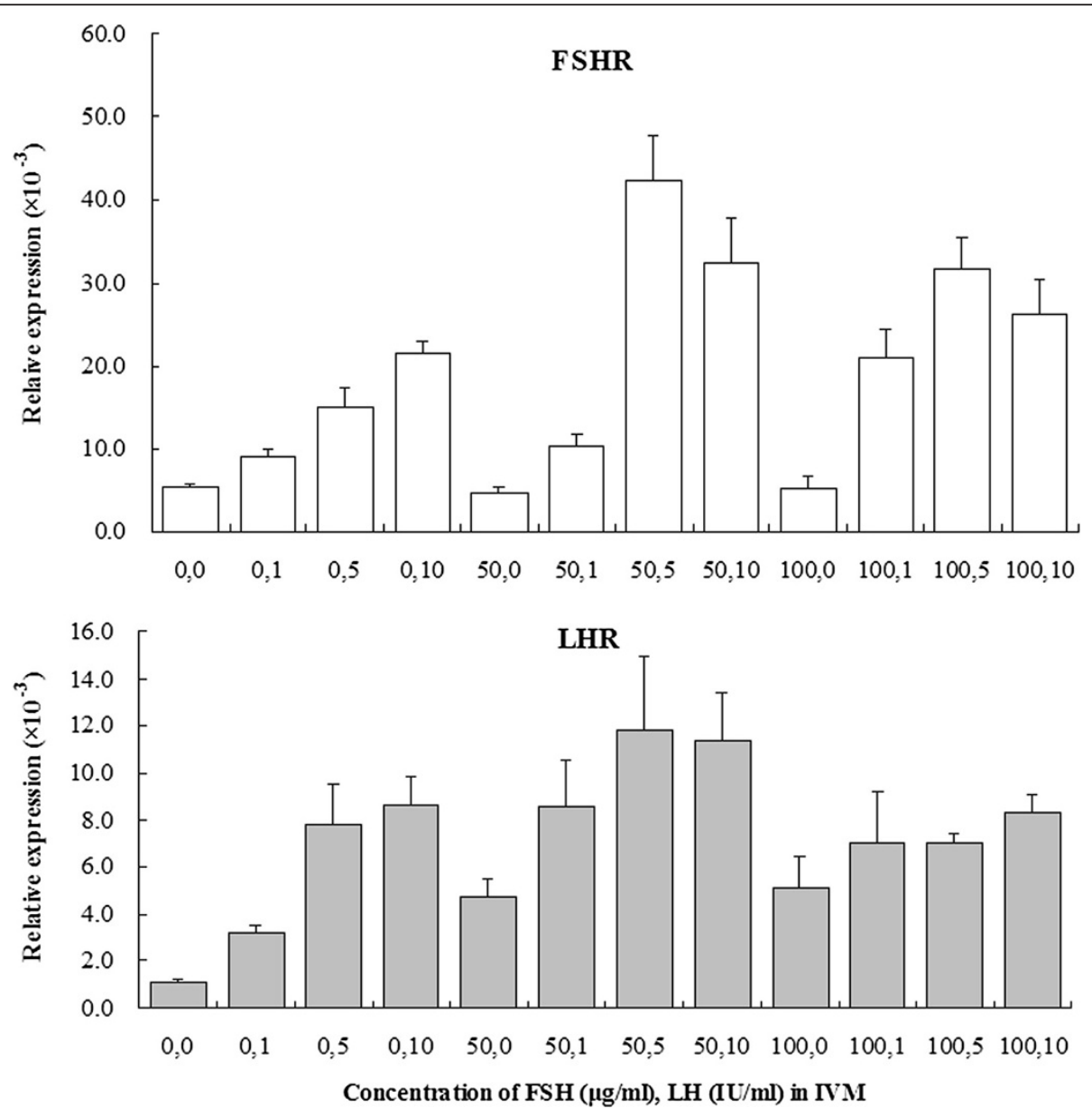

Figure 1 Effect of addition of FSH and LH in IVM media on FSHR and LHR mRNA expression in yak cumulus cells after $24 \mathrm{~h}$ IVM as determined by real-time PCR. The experiments were carried out in four replicates. The expression of these mRNAs was normalized to the expression of GAPDH measured in the same RNA preparation. Results were expressed as the mean \pm SD. 
mRNA were detected in yak cumulus cells after in vitro maturation, and the greatest expression was observed when the concentration of FSH and LH in IVM medium was $5 \mu \mathrm{g} / \mathrm{ml} \mathrm{FSH}$ and $50 \mathrm{IU} / \mathrm{ml} \mathrm{LH}$. The cumulus cells had higher numbers of $F S H$ receptors than $L H$ receptors. Addition of FSH in IVM media had a greater effect on increase of these receptors than that of LH.

\section{Concentration-dependent effect of MG132 from 18-24 h of maturation on subsequent embryonic development (Experiment 3)}

Results for COCs treated from 18 to 24 h of maturation with $0,10,20$ or $30 \mu \mathrm{M}$ MG132 are shown in Table 2. Treatment of COCs with $10 \mu \mathrm{M}$ MG132 in IVM medium increased $(P<0.05)$ the percentage of cleaved embryos (i.e., that were $\geq 2$ cells) becoming blastocysts. There was, however, no effect of $10 \mu \mathrm{M}$ MG132 on the cleavage rate. Treatment with $20 \mu \mathrm{M}$ MG132 had no effect on the cleavage rate and the percentage of cleaved embryos becoming blastocysts. However, treatment with $30 \mu \mathrm{M}$ MG132 had negative effect on subsequent development.

\section{Fertilization rates of oocytes treated with MG132 from 0-6 or 18-24 h of maturation (Experiment 4)}

Results are in Table 3. Addition of MG132 from 0-6 h of maturation reduced fertilization rate regardless of whether MG132 was also added at 18-24 h of maturation $(P<0.05)$, but treatment of COCs with $10 \mu \mathrm{M}$ MG132 increased $(P<0.05)$ the percentage of cleaved embryos becoming blastocysts, as also shown in Experiment 2.

\section{Discussion}

Yak oocyte competence for fertilization and ability to support embryonic development was affected by additions of FSH, LH and the proteasomal inhibitor MG132 during the maturation process. The optimal concentration of FSH and LH in IVM media was $5 \mu \mathrm{g} / \mathrm{ml} \mathrm{FSH}$ and $50 \mathrm{IU} /$ $\mathrm{ml}$ LH. The percentage of cleaved embryos becoming blastocysts could be further improved by MG132, but actions of MG132 depended on the time of addition and the

Table 2 Concentration-dependent effects of MG132 added from 18-24 h of maturation on yak embryonic development

\begin{tabular}{cccc}
\hline MG132 $(\boldsymbol{\mu M})$ & $\begin{array}{c}\text { No. of } \\
\text { oocytes }\end{array}$ & $\begin{array}{c}\text { Cleavage rate } \\
(\%)\end{array}$ & $\begin{array}{c}\text { Blastocyst } \\
\text { rate (\%) }\end{array}$ \\
\hline 0 & 265 & $76.8 \pm 2.0^{\mathrm{a}}$ & $14.1 \pm 2.2^{\mathrm{a}}$ \\
5 & 233 & $77.0 \pm 1.9^{\mathrm{a}}$ & $14.7 \pm 1.5^{\mathrm{a}}$ \\
10 & 247 & $79.8 \pm 2.2^{\mathrm{a}}$ & $18.1 \pm 2.8^{\mathrm{b}}$ \\
20 & 252 & $72.1 \pm 1.4^{\mathrm{a}, \mathrm{b}}$ & $12.5 \pm 2.2^{\mathrm{a}, \mathrm{c}}$ \\
30 & 226 & $69.2 \pm 1.6^{\mathrm{b}}$ & $10.6 \pm 1.3^{\mathrm{c}}$ \\
\hline
\end{tabular}

Three to five replicates were performed. The blastocyst rate was calculated as the percentage of the number of cleaved embryos. Values with different letters within the same columns differ $(P<0.05)$.
Table 3 Effects of timing of MG132 treatment (10 $\mu \mathrm{M})$ on yak embryonic development

\begin{tabular}{ccccc}
\hline $\begin{array}{c}\text { MG132, } \\
\text { 0-6 h }\end{array}$ & $\begin{array}{c}\text { MG132, 18- } \\
\mathbf{2 4 ~ h}\end{array}$ & $\begin{array}{c}\text { No. of } \\
\text { oocytes }\end{array}$ & $\begin{array}{c}\text { Cleavage } \\
\text { rate (\%) }\end{array}$ & $\begin{array}{c}\text { Blastocyst } \\
\text { rate (\%) }\end{array}$ \\
\hline Yes & Yes & 184 & $39.1 \pm 2.5^{\mathrm{a}}$ & $11.6 \pm 3.1^{\mathrm{a}}$ \\
Yes & No & 178 & $33.0 \pm 2.0^{\mathrm{b}}$ & $9.4 \pm 2.9^{\mathrm{a}}$ \\
No & Yes & 172 & $77.9 \pm 2.6^{\mathrm{c}}$ & $19.1 \pm 1.3^{\mathrm{b}}$ \\
No & No & 165 & $75.0 \pm 2.0^{\mathrm{c}}$ & $15.0 \pm 3.2^{\mathrm{c}}$ \\
\hline
\end{tabular}

Three to five replicates were performed. The blastocyst rate was calculated as the percentage of the number of cleaved embryos. Values with different letters within the same columns differ $(P<0.05)$

concentration. Yak oocyte competence was improved when $10 \mu \mathrm{M}$ MG132 was added during the last $6 \mathrm{~h}$ maturation (from 18-24 $\mathrm{h}$ of maturation) and reduced when added during the first $6 \mathrm{~h}$ of maturation.

The mammalian oocytes are surrounded by several layers of cumulus cells, with the corona cell being closest to the oocyte. FSH and LH stimulate cumulus cell expansion, nuclear maturation, cytoplasmic maturation, and improve embryonic development in mice [2,3], pig [4], cow [5], equine [6] and dog [7]. In previous studies of mice and rats, the cumulus cells had high numbers of FSH receptors, but little or no $L H$ receptors [19-21]. In bovines, it was reported that the FSH receptor and its mRNA were expressed in cumulus cells and granulosa cells, but not the mRNA of the $L H$ receptor [22]. In this study, we observed that an optimal concentration of $5 \mu \mathrm{g} / \mathrm{ml} \mathrm{FSH}$ and $50 \mathrm{IU} / \mathrm{ml} \mathrm{LH}$ in IVM medium increased yak oocyte competence for fertilization and ability to support embryonic development (Table 1), and FSHR and LHR mRNA expressions of cumulus cells. FSH was more effective than LH due to higher FSH receptor levels in cumulus cells of yak oocytes than the levels of the $L H$ receptor. In addition, treatment with FSH in IVM media had greater effect on the increase of FSHR and LHR mRNA expression level than that of LH (Figure 1).

Early in maturation, completion of meiosis I requires inactivation of maturation promoting factor (MPF) through a process mediated by proteasomal cleavage of ubiquitinated cyclin B1 [23]. In bovine, MG132 treatment from 0-6 h of maturation has been reported to increase the proportion of oocytes that were at metaphase I and decrease the number of oocytes that reached metaphase II at the end of maturation [11]. Therefore, inhibition of meiosis is likely a major cause for reduced oocyte competence in bovine oocytes. Inhibition of other proteasome-mediated events early in maturation may also be involved in reduced oocyte competence. For example, in the pig, MG132 can affect expression of genes involved in expansion of the extracellular matrix [24]. Similarly, in this study, we also observed that yak oocyte competence for development after fertilization was significantly reduced by addition of MG132 from 0-6 h of maturation (Table 3). 
The finding that treatment of yak COCs with $10 \mu \mathrm{M}$ MG132 late in maturation improves the percentage of cleaved embryos becoming blastocysts is consistent with other results showing beneficial effects of MG132 on aged mouse oocytes fertilized by intracytoplasmic sperm injection [9], parthenogenetically activated pig oocytes [10] and IVM bovine oocytes [11]. Beneficial effects of MG132 on nuclear remodeling, transcript abundance and embryonic development have also been shown for embryos constructed by somatic cell nuclear cloning in mammalian species [10,25-28]. Optimal results with MG132 were achieved at a concentration of $10 \mu \mathrm{M}$ - beneficial effects were generally not observed at lower or higher concentrations (Table 2). Similar effects have been seen in mouse, goat, pig and bovine oocytes used for SCNT $[25,29]$ and IVF [11]. In contrast to the observation by You et al. [11] in bovine oocytes, inhibition of proteasomes late in maturation can not improve the competence of yak oocyte to cleave in the present study (Tables 2 and 3). The mechanism by which MG132 late in maturation improves competence of the oocyte to support development is likely to involve arrest of processes mediated by proteasomes that ordinarily compromise the oocyte. In bovine oocytes, it was found that MG132 at the end of maturation increased relative expression of six proteins and decreased relative expression of 23 that are potentially important for oocyte competence [11].

\section{Conclusions}

An optimal concentration of FSH and LH improves oocytes competence for development after fertilization in yak. Treatment with MG132 early in maturation reduces fertilization rate and the proportion of oocytes and cleaved embryos that became blastocysts. Conversely, inhibition of proteasomes late in maturation can improve oocytes competence for development after fertilization.

\section{Competing interests}

The authors declare that they have no competing interests.

\section{Authors' contributions}

$X X$ and XDZ carried out all aspects of the study and wrote the manuscript. HRN and XRX participated in some parts of IVF. JCZ, JL, LW and YW participated in the experimental design. All authors read and approved the final manuscript.

\section{Acknowledgments \\ This work was supported by National Key Technology R\&D Program (No. 2012 BAD13B06) and Southwest University for Nationalities (12NZYTH07; 2011XWD-S0905).}

\section{Author details}

${ }^{1}$ College of Life Science and Technology, Southwest University for Nationalities, Chengdu 610041, People's Republic of China. ${ }^{2}$ College of Tibetan Plateau Research, Southwest University for Nationalities, Chengdu 610041, People's Republic of China.
Received: 20 February 2014 Accepted: 14 April 2014

Published: 22 April 2014

\section{References}

1. Eppig JJ: Coordination of nuclear and cytoplasmic oocyte maturation in eutherian mammals. Reprod Fertil Dev 1996, 8:485-489.

2. Eppig JJ: Gonadotropin stimulation of the expansion of cumulus oophori isolated from mice: general conditions for expansion in vitro. J Exp Zool 1979, 208:111-120.

3. Junk SM, Dharmarajan A, Yovich JL: FSH priming improves oocyte maturation, but priming with FSH or hCG has no effect on subsequent embryonic development in an in vitro maturation program. Theriogenology 2003, 59:1741-1749.

4. Singh B, Barbe GJ, Armstrong DT: Factors influencing resumption of meiotic maturation and cumulus expansion of porcine oocyte-cumulus cell complexes in vitro. Mol Reprod Dev 1993, 36:113-119.

5. Zuelke KA, Brackett BG: Luteinizing hormone-enhanced in vitro maturation of bovine oocytes with and without protein supplementation. Biol Reprod 1990, 43:784-787.

6. Dell'Aquila ME, Caillaud M, Maritato F, Martoriati A, Gérard N, Aiudi G, Minoia $P$, Goudet G: Cumulus expansion, nuclear maturation and connexin 43, cyclooxygenase-2 and FSH receptor mRNA expression in equine cumulus-oocyte complexes cultured in vitro in the presence of FSH and precursors for hyaluronic acid synthesis. Reprod Biol Endocrinol 2004, 2:44.

7. Lee HS, Seo YI, Yin XJ, Cho SG, Lee SS, Kim NH, Cho SK, Kong IK: Effect of follicle stimulation hormone and luteinizing hormone on cumulus cell expansion and in vitro nuclear maturation of canine oocytes. Reprod Dom Anim 2007, 42:561-565.

8. Calder MD, Caveney AN, Smith LC, Watson AJ: Responsiveness of bovine cumulus- oocyte-complexes (COC) to porcine and recombinant human $\mathrm{FSH}$, and the effect of $\mathrm{COC}$ quality on gonadotropin receptor and $\mathrm{Cx} 43$ marker gene mRNAs during maturation in vitro. Reprod Biol Endocrinol 2003, 1:14

9. Ono T, Mizutani E, Li C, Yamagata K, Wakayama T: Offspring from intracytoplasmic sperm injection of aged mouse oocytes treated with caffeine or MG132. Genesis 2011, 49:460-471.

10. You J, Kim J, Lee H, Hyun SH, Hansen PJ, Lee E: MG132 treatment during oocyte maturation improves embryonic development after somatic cell nuclear transfer and alters oocyte and embryo transcript abundance in pigs. Mol Reprod Dev 2012, 79:41-50.

11. You J, Lee E, Bonilla L, Francis J, Koh J, Blocket J, Chen S, Hansen PJ: Treatment with the proteasome inhibitor MG132 during the end of oocyte maturation improves oocyte competence for development after fertilization in cattle. PLOS One 2012, 7:e48613.

12. Wiener G, Han JL, Long RJ: The Yak. 2nd edition. Bangkok: The Regional Office for Asia and the Pacific of the Food and Agriculture Organization of the United Nations; 2003.

13. Zi XD, Yin RH, Chen SW, Liang GN, Zhang DW: Developmental competence of embryos derived from reciprocal in vitro fertilization between yak (Bos grunniens) and cattle (Bos taurus). J Reprod Dev 2009, 55:480-483

14. Guo X, Ding XZ, Pei J, Bao PJ, Liang CN, Chu M, Yan P: Efficiency of in vitro embryo production of yak (Bos grunniens) cultured in different maturation and culture conditions. J Appl Anim Sci 2012, 40:323-329.

15. Tervit HR, Whittingham DG, Rowson LEA: Successful culture in vitro of sheep and cattle ova. J Reprod Fertil 1972, 30:487-493.

16. Zi XD, Lu H, Yin RH, Chen SW: Development of embryos after in vitro fertilization of bovine oocytes with sperm from either yaks (Bos grunniens) or cattle (Bos taurus). Anim Reprod Sci 2008, 108:208-215.

17. Zi XD, Chen DW, Wang HM: Molecular characterization, mRNA expression of prolactin receptor (PRLR) gene during pregnancy, nonpregnancy in the yak (Bos grunniens). Gen Comp Endocrinol 2012, 175:384-388.

18. Pfaffl MW: A new mathematical model for relative quantification in real-time RT-PCR. Nucleic Acids Res 2001, 29:2002-2007.

19. Vanderhyden BC, Armstrong DT: Role of cumulus cells and serum on the in vitro maturation, fertilization, and subsequent development of rat oocytes. Biol Reprod 1989, 40:720-728.

20. Peng XR, Hsueh AJ, LaPolt PS, Bjersing L, Ny T: Localization of luteinizing hormone receptor messenger ribonucleic acid expression in ovarian cell 
types during follicle development and ovulation. Endocrinology 1991, 129:3200-3207.

21. Elvin JA, Clark AT, Wang P, Wolfman NM, Matzuk MM: Paracrine actions of growth differentiation factor-9 in the mammalian ovary. Mol Endocrinol 1999, 13:1035-1048.

22. van Tol HT, van Eijk MJ, Mummery $\mathrm{CL}$, van den Hurk R, Bevers MM: Influence of FSH and hCG on the resumption of meiosis of bovine oocytes surrounded by cumulus cells connected to membrana granulosa. Mol Reprod Dev 1996, 45:218-224.

23. Karabinova P, Kubelka M, Susor A: Proteasomal degradation of ubiquitinated proteins in oocyte meiosis and fertilization in mammals. Cell Tissue Res 2011, 346:1-9.

24. Nagyova E, Scsukova S, Nemcova L, Mlynarcikova A, Yi YJ, Sutovsky M, Sutovsky PNE: Inhibition of proteasomal proteolysis affects expression of extracellular matrix components and steroidogenesis in porcine oocyte-cumulus complexes. Domest Anim Endocrinol 2012, 42:50-62.

25. Gao S, Han Z, Kihara M, Adashi E, Latham KE: Protease inhibitor MG132 in cloning: no end to the nightmare. Trends Biotechnol 2005, 23:66-68.

26. Wu YG, Zhou P, Lan GC, Wang G, Luo MJ, Tan JH: The effects of delayed activation and MG132 treatment on nuclear remodeling and preimplantation development of embryos cloned by electrofusion are correlated with the age of recipient cytoplasts. Cloning Stem Cells 2007, 9:417-431.

27. Mizumoto $S$, Kato $Y$, Tsunoda Y: The developmental potential of parthenogenetic and somatic cell nuclear-transferred rat oocytes in vitro. Cloning Stem Cells 2008, 10:4453-4459.

28. Nakajima N, Inomata T, Kashiwazaki N: Treatment with proteasome inhibitor MG132 during cloning improves survival and pronuclear number of reconstructed rat embryos. Cloning Stem Cells 2008, 10:461-468.

29. Whitworth KM, Li R, Spate LD, Wax DM, Rieke A, Whyte JJ, Manandhar G, Sutovsky M, Green JA, Sutovsky P, Prather RS: Method of oocyte activation affects cloning efficiency in pigs. Mol Reprod Dev 2009, 76:490-500.

doi:10.1186/1477-7827-12-30

Cite this article as: Xiao et al:: Effect of addition of FSH, LH and proteasome inhibitor MG132 to in vitro maturation medium on the developmental competence of yak (Bos grunniens) oocytes. Reproductive Biology and Endocrinology 2014 12:30.

\section{Submit your next manuscript to BioMed Central and take full advantage of:}

- Convenient online submission

- Thorough peer review

- No space constraints or color figure charges

- Immediate publication on acceptance

- Inclusion in PubMed, CAS, Scopus and Google Scholar

- Research which is freely available for redistribution 